\title{
The Genomes of Desulfovibrio gigas and D. vulgaris
}

\author{
By JOHN R. POSTGATE, * HELEN M. KENT, ROBERT L. ROBSON AND \\ JULIAN A. CHESSHYRE
}

ARC Unit of Nitrogen Fixation, University of Sussex, Brighton BNI 9RQ, UK

(Received 16 January 1984; revised 9 February 1984)

\begin{abstract}
Two-dimensional electrophoresis of sequential double-restriction digests showed that the genome of Desulfovibrio gigas comprised $1.63 \times 10^{6} \mathrm{bp}\left(1.09 \times 10^{9} \mathrm{Dal}\right)$ of DNA; an ammonialimited chemostat population possessed an average of nine genomes per cell and a multiplying batch culture possessed $\sim 17$ genomes per cell. The genome size of $D$. vulgaris (Hildenborough) was $1.72 \times 10^{6}$ bp $\left(1.14 \times 10^{9} \mathrm{Dal}\right)$; a population from an ammonia-limited batch culture contained four genomes per cell. Control digestions and analyses with Escherichia coli GM4 agreed reasonably with published values: a genome size of $3.95 \times 10^{6} \mathrm{bp}$ and approximately two genomes per cell from a stationary batch culture in glucose minimal medium. Desulfovibrio gigas carried two plasmids of $\sim 70 \mathrm{MDal}\left(1.05 \times 10^{5} \mathrm{bp}\right)$ and $\sim 40 \mathrm{MDal}\left(6 \times 10^{4} \mathrm{bp}\right) ; D$. vulgaris (Hildenborough) contained one of $\sim 130 \mathrm{MDal}\left(1.95 \times 10^{5} \mathrm{bp}\right)$. Single plasmids were also detected in a second strain of $D$. vulgaris and in strain Berre sol of $D$. desulfuricans but not in 10 other desulfovibrios including representatives of $D$. desulfuricans, $D$. vulgaris, $D$. salexigens and D. africanus.
\end{abstract}

\section{INTRODUCTION}

Published information on the genomes of Desulfovibrio is restricted to the $\mathrm{G}+\mathrm{C}$ ratios of various species (collated by Postgate, 1984) and the exploitation of DNA-rRNA hybridization by Pace \& Campbell (1971) to illustrate inter-species relationships.

Yee \& Inouye (1982) described a new electrophoretic procedure for sizing the prokaryotic genome. In principle, a digest of genomic DNA with a six-base recognition restriction enzyme is resolved by electrophoresis in agarose. The DNA in a strip of the agar is re-digested with a second such restriction enzyme and resolved by electrophoresis at right angles to the original current. Appropriate molecular weight markers are included at the second stage. Fragments are then sized with reference to the markers and summed to give the genome size. This procedure is complementary to, and consistent with, DNA reassociation curves, analyses of minimum DNA contents or sizing of electron micrographs (see Yee \& Inouye, 1982).

We have applied this technique to single strains of Desulfovibrio gigas and D. vulgaris, in which we have also observed plasmids by conventional electrophoresis; we have also examined 12 other strains of Desulfovibrio for plasmids and observed them in two.

\section{METHODS}

Desulfovibrio gigas (NCIMB 9332), kindly provided by Dr E. C. Hatchikian, (CNRS, Marseille, France), was grown in a simple wier-type chemostat $\left(V_{\mathrm{F}} 540 \mathrm{ml}\right)$ at $D=0.025$ or $0.03 \mathrm{~h}^{-1}$ under $\mathrm{O}_{2}$-free $\mathrm{N}_{2}$ at $28^{\circ} \mathrm{C}$ in lactatesulphate medium $\mathrm{C}$ (Postgate, 1984) modified so that the population was limited by the $\mathrm{N}$ supply by including only $0.03 \mathrm{~g} \mathrm{NH}_{4} \mathrm{Cl} \mathrm{1}^{-1}$. Periodic cultural and visual checks were made for contamination (Postgate, 1984); none was present in any of the experiments reported here. Desulfovibrio vulgaris Hildenborough (NCIMB 8303) was grown in batch cultures $\left(20\right.$ or $200 \mathrm{ml}$ ) to stationary phase under $\mathrm{N}_{2}$ and was taken as $\mathrm{N}$-limited. Desulfovibrio gigas and some other desulfovibrios (Table 2) were grown in normal medium $\mathrm{C}$ with extra $\mathrm{NaCl}$ as necessary. Escherichia coli 
GM4 (a pro leu thi lac $Y$ recA rpsL end A derivative of $\mathrm{K} 12$ ) was grown in flasks in air at $28^{\circ} \mathrm{C}$ shaken in the minimal glucose medium of Davis \& Mingioli (1950) containing proline, leucine (each at $30 \mu \mathrm{g} \mathrm{ml}^{-1}$ ) and thiamin $\left(1 \mu \mathrm{g} \mathrm{ml}^{-1}\right)$.

DNA was extracted from $D$. gigas by the method of Marmur (1960) and tested with a variety of restriction enzymes: EcoRI, BamHI, BstEII, SmaI, XhoI, HindIII, SalI (BRL). Digestions were performed using the reaction buffer prescribed for each enzyme by the manufacturer. The first four gave good digests according to onedimensional gels; the last three gave poor digests with only few fragments. Comparable tests were performed on DNA from D. vulgaris Hildenborough ( $X h o I$ gave satisfactory digests with this material), and the genomes of the two desulfovibrios were sized as described by Yee \& Inouye (1982) using restriction enzymes which had given good digests. Each strain was examined twice, using different pairs of restriction enzymes. Desulfovibrio gigas DNA was digested with Eco RI or BamHI and, after electrophoresis, was re-digested in situ with BstEII. Desulfovibrio vulgaris DNA was digested with $E c o$ RI or $X h o I$ followed by BstEII. The standard marker was a HindIII digest of phage $\lambda$ DNA (Boehringer-Mannheim). The procedure used with E. coli DNA was essentially similar (Robson et al., 1984). For the gels shown in Fig. 1, genomic DNA $(\sim 20 \mu \mathrm{g})$ was digested for $120 \mathrm{~min}$ at $37^{\circ} \mathrm{C}$ with 40 units EcoRI and one half of the digest was resolved by electrophoresis $\left(22 \mathrm{~h}\right.$ at $\left.1.4 \mathrm{~V} \mathrm{~cm}^{-1}\right)$ in $0.7 \%(\mathrm{w} / \mathrm{v})$ agarose gel. A strip of digested DNA was cut from the gel for re-digestion and the remainder was stained with ethidium bromide and inspected to identify the portion of the strip which carried the digested DNA. That portion was soaked in ' $E$ ' buffer [sodium acetate $(20 \mathrm{mM})$, Tris/acetate $(40 \mathrm{mM}), \mathrm{Na}_{2}$ EDTA $(2 \mathrm{mM}) \mathrm{pH} 8 \cdot 0$ ] and transferred to a perspex container (Robson et al., 1984). It was soaked overnight at $4{ }^{\circ} \mathrm{C}$ in reaction buffer containing 90 units BstEII and then re-digested for $6 \mathrm{~h}$ at $60^{\circ} \mathrm{C}$. The strip was removed, washed in fivefold-diluted buffer and applied to the edge of a second gel together with marker DNA. After electrophoresis the gel was stained with ethidium bromide, photographed and the print enlarged for sizing.

Plasmids were extracted as described by Cannon (1980). Samples were applied to $0.7 \%$ agarose in Cannon's TAE Buffer, resolved over $16 \mathrm{~h}$ at $4.4 \mathrm{~V} \mathrm{~cm}^{-1}, 80 \mathrm{~mA}$, and photographed under $254 \mathrm{~nm}$ light after staining with $1 \mu \mathrm{g}$ ethidium bromide $\mathrm{ml}^{-1}$. A plasmid preparation from Azotobacter chroococcum strain MCC-1, which carries five cryptic plasmids (Robson et al., 1984) served as standard for approximate molecular weight assessments; the smallest plasmid was not normally visible in our gels. Strains recorded as displaying no plasmids were checked three times in all.

Protein was measured by the Lowry method with BSA fraction 5 (Sigma; $1 \mathrm{mg} \mathrm{ml}^{-1}$ ) as standard, checked to an absorbance of 0.667 at $279 \mathrm{~nm}$. DNA was measured by the diphenylamine method of Burton (1956) using $80 \mathrm{ml}$ culture samples concentrated $\sim 20$-fold. A freeze-thawed solution of herring sperm DNA (BoehringerMannheim) was used as standard. Bacterial dry weights were obtained by centrifuging triplicate $20-40 \mathrm{ml}$ samples of culture (absorbance 0.36 to 0.4 at $540 \mathrm{~nm}$ ), resuspending in $1 \mathrm{ml}$ lactate-free medium $\mathrm{C}$, measuring the volume and drying down $1 \mathrm{ml}$ to constant weight at $80^{\circ} \mathrm{C}$ compared with $1 \mathrm{ml}$ suspending medium. Bacterial numbers were estimated in a Thoma bacterial counting chamber $(20 \mu \mathrm{m}$ depth), diluting the population and heating it briefly to $80^{\circ} \mathrm{C}$ to arrest motility if necessary; the systematic error of Norris \& Powell (1961) was disregarded. Absorbance values were read at $540 \mathrm{~nm}$ in a $1 \mathrm{~cm}$ cell in an EEL spectrophotometer and converted to dry weights.

\section{RESULTS}

Table 1 gives the analytical data for D. gigas, D. vulgaris and E. coli cultures grown at $28^{\circ} \mathrm{C}$. Protein contents of the organisms were relatively low, consistent with the $\mathrm{N}$-limited status of the populations analysed. The substantial difference in total count between the two species, for a modest difference in absorbance, reflects the relatively large size of $D$. gigas (see Postgate, 1984). The mean DNA content per cell was $9.25 \times 10^{-15} \mathrm{~g}$ for $D$. vulgaris and $17.7 \times 10^{-15} \mathrm{~g}$ for the chemostat populations of $D$. gigas. Figure $1(a, b, c)$ shows double-digest gels (EcoRI followed by

Table 1. Analytical data for Desulfovibrio species and E. coli

\begin{tabular}{|c|c|c|c|c|c|c|c|}
\hline \multirow[b]{2}{*}{ Organism } & \multirow[b]{2}{*}{$\begin{array}{l}\text { Population } \\
\left(\text { cells ml }{ }^{-1} \text { ) }\right.\end{array}$} & \multirow[b]{2}{*}{$\begin{array}{c}\text { Dry wt } \\
\left(\mu \mathrm{g} \mathrm{ml}^{-1}\right)\end{array}$} & \multirow[b]{2}{*}{$A_{540}^{1 \mathrm{~cm}}$} & \multicolumn{2}{|c|}{ DNA } & \multicolumn{2}{|c|}{ Protein } \\
\hline & & & & $\left(\mu \mathrm{g} \mathrm{ml}^{-1}\right)$ & $(\%$ dry wt) & $\left(\mu \mathrm{g} \mathrm{ml}^{-1}\right)$ & $(\%$ dry wt) \\
\hline D. gigas & $3.04 \times 10^{8}$ & 343 & $0 \cdot 38$ & $4 \cdot 75$ & $1 \cdot 38$ & 215 & 62 \\
\hline & $3.17 \times 10^{8}$ & 350 & $0 \cdot 39$ & $5 \cdot 05$ & 1.44 & 180 & 51 \\
\hline & $4.5 \times 10^{7 *}$ & 99 & $0 \cdot 14$ & $1 \cdot 4$ & 1.42 & - & - \\
\hline D. vulgaris & $6.97 \times 10^{8}$ & 200 & $0 \cdot 31$ & $5 \cdot 75$ & $2 \cdot 8$ & 100 & 50 \\
\hline E. coli & $7 \cdot 3 \times 10^{8}$ & 297 & $0 \cdot 37$ & $6 \cdot 4$ & $2 \cdot 15$ & - & $63 \dagger$ \\
\hline
\end{tabular}

* From batch culture in medium $\mathrm{C}$, see text.

$\uparrow$ From a second experiment. 


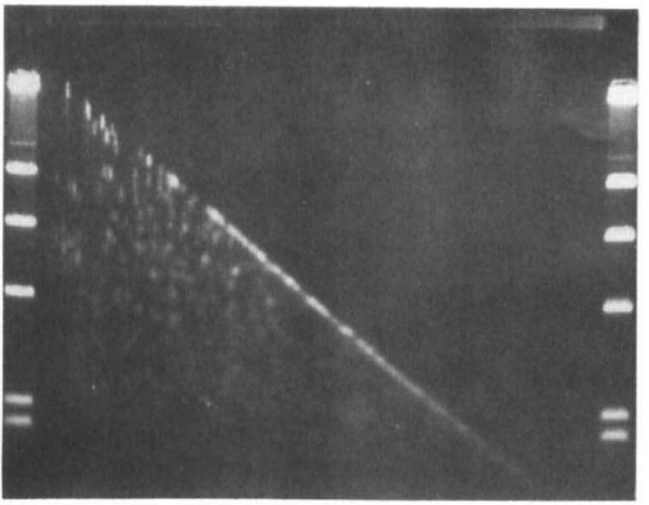

(a)

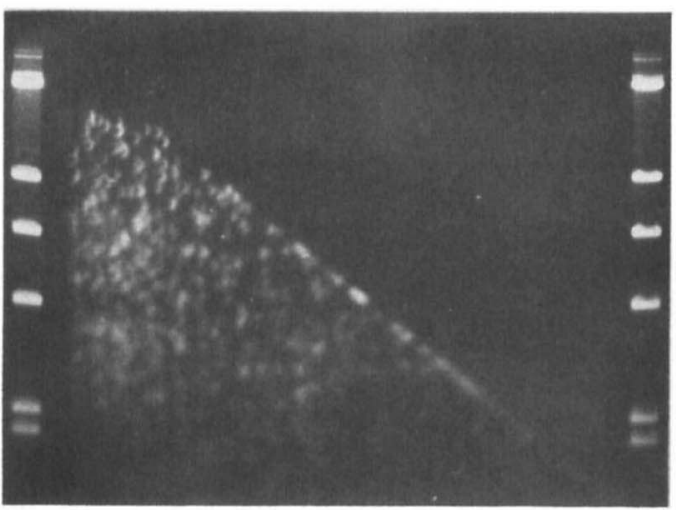

(c)

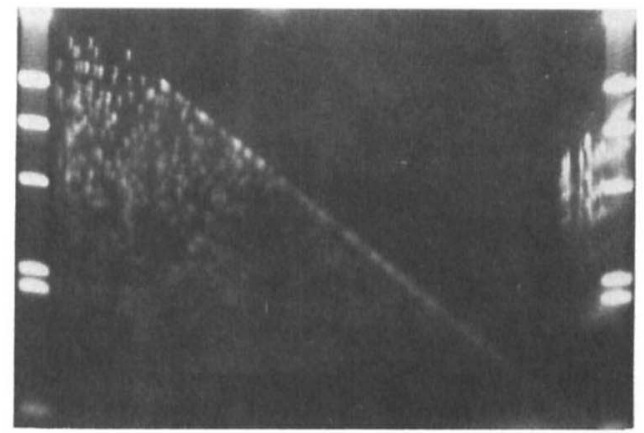

(b)

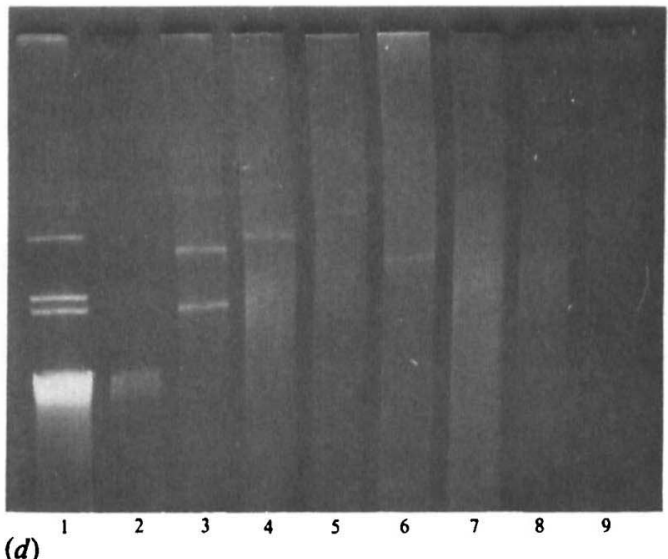

Fig. 1. Two-dimensional double restriction digests of $(a)$ D. gigas, (b) D. vulgaris Hildenborough, and (c) $E$. coli GM4. Marker DNA (HindIII fragments of phage $\lambda$ ) was run at the extremities. (d) Demonstration of plasmids in certain strains of Desulfovibrio; lane 1, A. chroococcum MCC-1 as control with plasmids of $190,90,45$ and $40 \mathrm{MDal}$ visible as well as smear of chromosomal DNA; lane 2 is irrelevant. Lane 3, D. gigas; 4, D. desulfuricans Berre sol; 5, D. vulgaris Hildenborough; 6, D. vulgaris Wandle; 7, D. africanus Walvis bay; 8, D. vulgaris Groningen; 9, D. salexigens California 43:63. For further details of strains see Table 2 .

BstEII) for D. gigas, D. vulgaris and E. coli. Although D. gigas and D. vulgaris have similar DNA base compositions at $\sim 65 \% \mathrm{G}+\mathrm{C}$ (see Postgate, 1984), the patterns of the double digests show no resemblance, consistent with their being different species; comparative gels of two strains of $E$. coli, run in this laboratory, were almost identical. The number of fragments and pattern of the E. coli DNA gel immediately suggest that it has a larger genome than Desulfovibrio. Sizing and enumeration of the spots with subjective allowance for overlap gave mean genome sizes of 1.63 $\pm 0.02 \times 10^{6}$ bp for $D$. gigas and $1.72 \pm 0.02 \times 10^{6}$ bp for D. vulgaris with a variance of $8 \%$, corresponding to an average of $9 \cdot 1$ genomes per cell of $D$. gigas and $4 \cdot 1$ genomes per cell of $D$. vulgaris. Escherichia coli GM4 had a genome size of $3.94 \times 10^{6} \mathrm{bp}$, corresponding reasonably to published sizes collated by Yee \& Inouye (1982); a similar calculation using the data in Fig. 1 indicated $2 \cdot 1$ genomes per cell.

The high genome complement of $D$. gigas prompted us to examine non- $\mathrm{N}$-limited populations actively growing in batch culture in medium $C$. The population in Table 1 had the normal percentage of DNA per unit dry weight but possessed an average of 17.2 genomes per cell.

Figure $1(d)$ depicts one-dimensional gels of covalently closed circular plasmid DNA extracted from a variety of strains of Desulfovibrio. Desulfovibrio gigas possessed two plasmids of approximately 70 and $40 \mathrm{MDal} ; D$. vulgaris strain Hildenborough had a plasmid of about 
Table 2. List of strains of Desulfovibrio tested for plasmids

For further details of strains see Postgate (1984).

\begin{tabular}{llccc}
\multicolumn{1}{c}{ Species } & \multicolumn{1}{c}{ Strain } & $\begin{array}{c}\text { NCIMB } \\
\text { no. }\end{array}$ & Habit* & $\begin{array}{c}\text { Plasmids } \\
\text { (MDal) }\end{array}$ \\
$\begin{array}{llcc}\text { D. gigas } \\
\text { D. desulfuricans }\end{array}$ & \multicolumn{1}{c}{ Berre sol } & 9332 & $\mathrm{f}$ & 40,70 \\
& Norway 4 & 8388 & $\mathrm{f}$ & 90 \\
& Canet 41 & 8310 & $\mathrm{~s}$ & 0 \\
& Teddington $\mathrm{R}$ & 8393 & $\mathrm{~s}$ & 0 \\
& El Agheila Z & 8312 & $\mathrm{f}$ & 0 \\
D. vulgaris & Hildenborough & 8380 & $\mathrm{~s}$ & 0 \\
& Wandle & 8303 & $\mathrm{f}$ & 130 \\
G. vulgaris & Mroningen & 8306 & $\mathrm{f}$ & 80 \\
subsp. oxamicus & Monticello 2 & 11779 & $\mathrm{f}$ & 0 \\
D. africanus & Benghazi & 9442 & $\mathrm{f}$ & 0 \\
D. salexigens & Walvis Bay & 8401 & $\mathrm{f}$ & 0 \\
& British Guiana & 8397 & $\mathrm{~s}$ & 0 \\
& California 43:63 & 8403 & $\mathrm{~s}$ & 0 \\
& & 8364 & $\mathrm{~s}$ & 0
\end{tabular}

* Fresh water (f) or saline (s) habit; $2.5 \% \mathrm{NaCl}$ was added to medium $\mathrm{C}$ for the latter.

$130 \mathrm{MDal}$, and single plasmids of about 80 and 90 Mdal can be seen in D. vulgaris strain Wandle and $D$. desulfuricans strain Berre sol. None was found in the 10 other strains listed in Table 2. The two plasmids of $D$. gigas were stable in that they were conserved over $90 \mathrm{~d}$ ( 70 doublings) in the chemostat as well as over seven subcultures in the sulphate-free fumarate medium of Miller \& Wakerley (1966).

\section{DISCUSSION}

Rapidly growing unicellular prokaryotes initiate chromosome replication in phase with their doubling time so, since the rate of chromosome duplication may be slower than the rate of cell duplication, individuals may carry DNA equivalent to more than one chromosome (see, for example, Pritchard et al., 1969). We attribute our finding of an average of about two chromosomes per cell in E. coli GM4 to this phenomenon. The presence of an average of 9 to 17 genomes per cell in D. gigas might reflect a high frequency of initiation of replication combined with a remarkably low rate of DNA synthesis, but it is more likely to reflect multiple genomes in this organism. High chromosome copy numbers are known among unicellular prokaryotes. For example, DNA reassociation curves show that Azotobacter vinelandii is a multigenomic unicellular prokaryote which normally possesses an average of 20 to 40 genomes per cell (Sadoff et al., 1979), a finding confirmed in principle in our laboratory for A. chroococcum (Robson et al., 1984). Similar studies with Micrococcus radiodurans (Hansen, 1978) indicated four to eight genomes per cell depending on the growth rate, a character which may be relevant to its radiation resistance and which was confirmed by studies of transformation frequencies (Tirgari \& Moseley, 1980). Multiple chromosomes were implied by the study by Mann \& Carr (1974) of the unicellular cyanobacterium Anacystis nidulans. Although D. gigas appears also to be a multinucleate prokaryote, the status of $D$. vulgaris, with an average of four genomes per cell, is on the borderline and studies of the effect of growth rate would be needed to establish whether it ever reaches a mean copy number of one chromosome per cell.

The genomes of the two desulfovibrios studied are completely different but both are small: around $1.1 \times 10^{9}$ Dal compared with $2.56 \times 10^{9}$ Dal for $E$. coli in our hands and $3.793 \times$ $10^{9} \mathrm{Dal}$ for Myxococcus xanthus (Yee \& Inouye, 1982); they are comparable in size to the genomes of certain Brucellaceae or Neisseria catarrhalis (Bak et al., 1970). The small genome may reflect the rather limited metabolic capabilities of these species and their strictly anaerobic habit (see Postgate, 1984). 
The genus Desulfovibrio now joins the many groups of prokaryotes in which cryptic plasmids are found but, if our limited survey is any guide, they show no consistency as regards size, multiplicity or incidence among these bacteria. Useful discussion of their roles must await the preparation of cured strains or appropriate DNA probes. Our data provide little information concerning their copy numbers. We have seen no particularly intense bands in restriction digests such as occur when there is a high plasmid copy number relative to the chromosome. Their stability requires an average of only one per cell, yet they could equal or even exceed by a small margin the chromosomal copy numbers. If there is just one copy of each plasmid per chromosome, then over $10 \%$ of the genome of $D$. gigas or D. vulgaris Hildenborough is plasmid DNA.

We thank Dr Germaine Stanier for drawing our attention to the situation in cyanobacteria.

\section{REFERENCES}

BaK, A. L., Christiansen, C. \& Stenderup, A. (1970). Bacterial genome sizes determined by DNA renaturation studies. Journal of General Microbiology 64, 377-380.

BurTon, K. (1956). A study of the conditions and mechanism of the diphenylamine reaction for the colorimetric estimation of deoxyribonucleic acid. Biochemical Journal 62, 315-323.

Cannon, F. C. (1980). Genetic studies with diazotrophs. In Methods for Evaluating Biological Nitrogen Fixation, pp. 367-413. Edited by F. J. Bergersen. Chichester: Wiley.

Davis, B. D. \& Mingioli, E. S. (1950). Mutants of Escherichia coli requiring methionine or vitamin $\mathbf{B}_{12}$. Journal of Bacteriology 60, 17-28.

HANSEN, M. T. (1978). Multiplicity of genome equivalents in the radiation-resistant bacterium Micrococcus radiodurans. Journal of Bacteriology 134, 7175.

ManN, N. \& Carr, N. G. (1974). Control of macromolecular composition and cell division in the bluegreen alga Anacystis nidulans. Journal of General Microbiology 83, 399-405.

MARMUR, J. (1960). A procedure for the isolation of deoxyribonucleic acid from microorganisms. Journal of Molecular Biology 3, 208-218.

Miller, J. D. A. \& Wakerley, D. S. (1966). Growth of sulphate-reducing bacteria by fumarate dismutation. Journal of General Microbiology 43, 101-107.

NORRIS, K. P. \& Powell, E. O. (1961). Improvements in determining total counts of bacteria. Journal of the Royal Microscopical Society 80, 107-119.
PACE, B. \& CAMPBell, L. L. (1971). Homology of ribosomal ribonucleic acid of Desulfovibrio species with Desulfovibrio vulgaris. Journal of Bacteriology 106, 717-719.

Postgate, J. R. (1984). The Sulphate-Reducing Bacteria, 2nd edn. Cambridge: Cambridge University Press.

Pritchard, R. H., Barth, P. T. \& Collins, J. (1969). Control of DNA synthesis in bacteria. Symposia of the Society for General Microbiology 19, 263-297.

Robson, R. L., Chesshyre, J. A., Wheeler, C., Jones, R., Woodley, P. R. \& Postgate, J. R. (1984). Genome size and complexity in Azotobacter chroococcum. Journal of General Microbiology 130, 16031612.

SAdoff, H. L., Shimei, B. \& Ellis, S. (1979). Characterization of Azotobacter vinelandii deoxyribonucleic acid and folded chromosomes. Journal of Bacteriology 138, 871-877.

TIRgari, S. \& Moseley, B. E. B. (1980). Transformation in Micrococcus radiodurans: measurement of various parameters and evidence for multiple, independently segregating genomes per cell. Journal of General Microbiology 119, 287-296.

YEE, T. \& INOUYE, M. (1982). Two-dimensional DNA electrophoresis applied to the study of DNA methylation and the analysis of genome size in Myxococcus xanthus. Journal of Molecular Biology 154, 181-196. 